\title{
Evaluation of Maize Top Cross Hybrids for Grain Yield and Associated Traits in Three Agro- Ecological Zones in Ghana
}

\author{
Emmanuel G. Vah ${ }^{1 *}$, Ndebeh J. ${ }^{2}$, Akromah R. ${ }^{3}$, Obeng- Antwi K. ${ }^{4}$ \\ ${ }^{1}$ Agronomist, Project Management Unit (PMU), Ministry of Agriculture, Liberia \\ ${ }^{2}$ Central Agricultural Research Institute (CARI), Suakoko District, Bong County, Liberia \\ ${ }^{3}$ Department of Crop and Soil Sciences, Faculty of Agriculture, Kwame Nkrumah, University of Science and Technology, \\ Kumasi, Ghana \\ ${ }^{4}$ Crop Research Institute (CRI) Fumesua Kumasi Ashanti Region, Ghana
}

\begin{abstract}
Maize (Zea mays L.) is an important food crop in Ghana, but its productivity in farmers" fields throughout the country is generally low. The low grain yields can be attributed partly to the use of traditional low-yielding openpollinated varieties. In an attempt to increase maize productivity, 39 top cross hybrids were developed using 21 inbred lines and 3 open-pollinated varieties. The trial was set up in a randomized complete block design with two replications in three locations in southern Ghana. The overall objective of the study was to investigate traits which influence yields in top cross hybrids and to ascertain the yield potential of the hybrids in three agro-ecological zones in Ghana. The Genotypes were evaluated to determine agronomic performances and correlations between yield and yield component traits were calculated to assess the degrees of associations. Highly significant variations $(p<0.01)$ were observed among the maize genotypes for grain yield, cob length, cob diameter and kernel row $\operatorname{cob}^{-1}$ and significant variations $(P<0.05)$ for days to $50 \%$ tasseling, days to $50 \%$ silking and kernel row ${ }^{-1}$. On the contrary, there were no significant differences among the genotypes for plant height and ear height. The significant $(P<0.01)$ results for grain yield indicated the variable nature of the locations and differences in the performances of the genotypes evaluated. The mean grain yield was significantly $(p<0.01)$ higher for the top cross hybrids than for the local checks.
\end{abstract}

Keywords - Correlations, genotypes, grain yield, top cross hybrids, traits.

\section{INTRODUCTION}

Maize is the most extensively consumed cereal in Ghana with rising production since 1965 (FAO STAT., 2008;
Morris et al., 1999). The per capita consumption of maize in Ghana in 2011 was predicted at $43.8 \mathrm{~kg}$ (MOFA-SRID, 2011a) and a predicted domestic consumption of 1,750,000 metric tons in 2011. Maize is considered a major source of protein ranking only behind meat, fish and legumes in terms of yearly protein production (Dasbak et al., 2008).

In order to meet the growing needs of farmers in Ghana, more than twenty-five (25) improved varieties comprising open pollinated and hybrid maize varieties of varying maturity periods have been developed and subsequently released by the CSIR-CRI (Badu-Apraku et al., 1992; Sallah et al., 1997; Twumasi Afriyie et al., 1997). These released varieties have been extensively adopted by maize farmers throughout the country (Dankyi et al., 1997; Morris et al., 1999).

In spite of this success, smallholder farmers continue to meet difficulties in accessing improved maize seeds. Moreover, productivity of maize in farmers ${ }^{\text {ee }}$ fields all over Ghana is low. The average grain yields of maize nationwide rests at 1.89 metric tons ha-1 (MOFA-SRID, 2011a). However, with the use of appropriate inputs together with the adoption of improved practices, yields of 4 or 5 tons ha ${ }^{-1}$ can be realized by farmers (MOFA-SRID, 2006).

The cause of low productivity has been ascribed partly to the use of traditional low yielding open-pollinated varieties (MOFA-SRID, 2006). At present, there is a growing demand for use of hybrid seeds especially early and extraearly drought resistant materials with high grain yield potential that can provide early harvest to bridge the hunger gap before the harvest of a full-season crop (Pswarayi and Vivek, 2007), ideal for off-season planting and suitable for minor rainfall season production which tend to be very short. Regrettably, the National Maize Program does not 
have any early maturing commercial hybrid. It is in view of this that the study was aimed at the development of top cross hybrids as the most viable solution. Therefore, the overall objective of this study was to investigate traits which influence yields in top cross hybrids and to ascertain the yield potential of the hybrids in three (3) agro-ecological zones of Ghana.

\section{MATERIALS AND METHODS}

\subsection{Experimental sites}

The study was conducted in three locations in Southern Ghana, namely; Fumesua, Ejura and Kpeve. Fumesua is situated in the Ashanti region (Latitude $6^{\circ} 43^{\prime} \mathrm{N}$; Longitude $1^{\circ} 36^{\prime} \mathrm{W}$ ), and falls within the Forest ecological zone of Ghana. Similarly, Ejura is situated in the Ashanti region at Latitude $7^{\circ} 24^{\prime} \mathrm{N}$ and Longitude $1^{\circ} 21^{\prime} \mathrm{W}$ with an elevation of $228.7 \mathrm{~m}$ above sea level, and falls within the ForestSavannah transition zone. Kpeve is situated in the Volta region (Latitude $6^{\circ} 41^{\prime} \mathrm{N}$ and Longitude $00^{\circ} 21^{\prime} \mathrm{E}$ ) with an elevation of $513 \mathrm{~m}$, and falls within the Coastal Savanna transition zone. The three locations experience a bi-modal rainfall, with a major season stretching from April through July and minor from August to November.

\subsection{Maize varieties and inbred lines used for the study}

Twenty-seven genotypes including three open-pollinated varieties (normal OPV parents), three check varieties and 21 inbred lines (donor parents) were used for the study. The varieties were from the CSIR-CRI Maize Program while the tropical early maturing maize (TZEI white-endosperm) inbred lines were from the International Institute for Tropical Agriculture (IITA), Ibadan, Nigeria Maize Improvement Program.

\subsection{Experimental design and field layout}

The trial was laid out in a randomized complete block design (RCBD) with two replications per location. Each experimental unit was a two-row plot of $5.0 \mathrm{~m}$ long, spaced $0.75 \mathrm{~m}$ by $0.45 \mathrm{~m}$ between and within rows, respectively, with 11 hills per row.

\subsection{Development of top cross hybrids}

A total of 39 top cross hybrids were formed using three OPVs and 21 inbred lines (testers). The generation of top cross hybrids was carried out between May to August 2012 at CRI. Controlled (hand) pollination was carried out approximately 60 days after planting at the CRI breeding nursery to prevent contamination. Prior to the appearance of the silk, developing ears were covered with a crystal clear plastic bag to make sure that emerging silks were not contaminated with undesirable pollen. At anthesis, pollen was collected from desirable plants in the individual inbred lines using brown tassel bags, bulked for each inbred line and used to pollinate agronomically good plants in the open-pollinated varieties which served as female parents.

A day prior to artificial crossing, the tassel of the male parent was covered with a brown tassel bag. This permitted fresh, uncontaminated pollen to be collected for use for the crosses the next morning. At harvest five clean cobs from each line with good husk cover were selected. These were de-husked, sun dried, shelled and put in separate envelopes and tagged.

\subsection{Evaluation of top cross hybrids}

Seeds collected from clean $\mathrm{F}^{1}$ cobs were constituted into a trial and planted for evaluation in October 2012 in each of the three locations. A total of 42 entries comprising $39 \mathrm{~F}^{1}$ hybrids and three early maturing elite varieties (Akposoe, Aburohemaa and Omankwa) used as checks were utilized in the trial. These elite OPVs were included as checks because the National Maize Program did not have any early maturing commercial hybrids. Two guard rows were planted at both sides of the experimental field to protect the trials.

\subsection{Cultural/management practices}

The trial site was carefully prepared by plowing and harrowing using tractor. This was carried out to manage weeds, provide good soil aeration and to obtain good seedling emergence and root penetration. Three seeds were sown in each hill (planting hole) for each set of genotypes and thinned to two plants per hill two weeks after emergence to give a final plant population density of approximately 60,000 plants per hectare. During the first three weeks of growth, the plants were irrigated using the sprinkler irrigation system at CRI. The trials were kept weed-free with the application of gramoxone and atrazine as pre- and post-emergence herbicides and manual hoeing. Fertilizer (NPK-15-15-15) was applied as basal after two weeks of planting and urea as top dressing after five weeks for optimum plant growth at each location. All trial management practices were based on the recommendations for each location.

\subsection{Data collection}

The following agronomic parameters were measured:

1) Days to tasseling (DYTS) - were recorded as number of days from planting to the time $50 \%$ of plant had fully 
emerged tassels; 2) Days to silking (DYSK) - were recorded as number of days from planting to the time $50 \%$ of plants had completely extruded silks; 3) Plant height (PHT)- the height of five randomly selected plants in centimeters were measured with a graduated measuring stick from soil surface to the last node; 4) Ear height (EHT) - the height of five plants in centimeters from the soil surface to the node on which the uppermost ear sits were measured from the same plant from which plant heights were recorded; 5) $\mathrm{Cob}$ length $(C O L)$ - the length of cobs in centimeters were measured using a caliper; 6) Cob diameter (COD) - the diameter of cobs in centimeters were also measured using a caliper; 7) Kernel rows $\mathrm{cob}^{-1}$ (KRPC) - the number of rows $\mathrm{cob}^{-1}$ of five cobs of each line was counted and the average recorded; 8) Kernel row ${ }^{-1}$ (KPR) - the number of kernels row $^{-1}$ of five cobs of each line was counted and the average recorded; 9) Grain Yield (GY) - was determined by means of converting yields plot ${ }^{-1}$ into grain yield ha ${ }^{-1}$. The formula used for the calculation of grain yield was:

$$
\text { Grain yield }\left(\mathrm{kg} \mathrm{ha}^{-1)}=\frac{\text { F.W. }\left(\mathrm{kg} \mathrm{plot}^{-1}\right)(100 \text {-moisture \%) } \mathrm{x} \mathrm{S} \mathrm{x} \mathrm{10,000}}{(85) \times \text { Harvested area (plot size })}\right.
$$

Where,

F.W. = Fresh weight of ear in $\mathrm{kg}$ at harvest

Moisture percentage $=$ Grain moisture content at harvest

$85=$ moisture percentage used was $15 \%$

$\mathrm{S}=$ Shelling co-efficient $(0.80)$

\subsection{Statistical analysis}

Data were analyzed using the Statistical Analysis System (SAS) version 9.2 (SAS Institute Incorporated, 2002). Data from each location were subjected to Analysis of Variance (ANOVA) individually to explore differences among entries for all traits and pooled across locations to determine $\mathrm{G} \times \mathrm{E}$ interactions. Means separation was carried out using least significant difference (lsd). Correlations among grain yield and yield contributing characters were examined. GGE biplot analysis (Yan, 2001) was used to assess yield stability among the maize varieties.

\section{RESULTS AND DISCUSSION}

3.1 Mean square analysis for agronomic traits Highly significant $(\mathrm{P}<0.01)$ differences among locations were observed for the 42 genotypes for grain yield, days to
$50 \%$ tasseling, days to 50\% silking, plant height, ear height, cob length, cob diameter, kernel row $\mathrm{cob}^{-1}$ and kernel row ${ }^{-1}$ (Table 1). For genotypes, variations were highly significant $(\mathrm{P}<0.01)$ for grain yield, cob length, cob diameter and kernel row $\mathrm{cob}^{-1}$ and significant $(\mathrm{P}<0.05)$ for days to $50 \%$ tasseling, days to $50 \%$ silking and kernel row $^{-1}$. On the contrary, there were no significant differences among the genotypes for plant height and ear height. Apart from grain yield, differences due to the interaction (genotype $\mathrm{x}$ location) were not significant for all the traits studied. Yield differences could be due to differences in soil conditions and rainfall patterns at the different sites. Differences due to location influences were similarly noted by Sallah et al. (2004) when they studied genotype by environment interaction effects of three maturity groups of maize at the same sites. Differences among locations may also be due to the fact that the genotypes used were from parents of diverse genetic backgrounds.

The genotypic variations found were due to the diverse backgrounds from which the genotypes used in the study were developed. This result was in agreement with findings by Sallah et al. (2001) and Soza et al. (1996) and these authors also used open-pollinated varieties and hybrids. Genotype by location interaction for grain yield may be due to differences among the sites in soil fertility, relative humidity, season and temperature, all factors which affect performance. Similar findings were cited by Butron et al. (2002) and these imply that the genotypes should be partially released for locations where the performance was most favorable (Ogunbodede et al., 2001). Moreover, the observed lack of significant means squares for $\mathrm{G} \times \mathrm{E}$ of plant height, ear height, days to $50 \%$ silking, days to $50 \%$ tasseling amongst others showed that these parameters were stable across the three sites used for the study. Genotype $x$ location interaction has, over the years, continued to cause setback for researchers which necessitate the need to carry out multi-location yield trials to enable plant breeders to categorize and select genotypes that are high yielding with specific or wide-ranging adaptation to diverse agroecological zones, prior to variety release. Information generated from these multi-location trials could be useful for state-run breeding program by identifying the appropriate breeding materials with advantageous agronomic qualities at test sites (Badu-Apraku et al., 2010). 
Table.1: Combined mean squares and degrees of freedom from ANOVA for agronomic traits of top cross hybrids and checks

\begin{tabular}{|c|c|c|c|c|c|c|c|c|c|c|}
\hline \multirow[b]{2}{*}{ Source } & \multirow[b]{2}{*}{ DF } & \multirow[b]{2}{*}{ GY } & \multirow[b]{2}{*}{ DYTS } & \multirow{2}{*}{$\begin{array}{l}\text { Mean } \\
\text { DYSK }\end{array}$} & \multirow{2}{*}{$\begin{array}{l}\text { Squares } \\
\text { PHT }\end{array}$} & \multirow[b]{2}{*}{ EHT } & \multirow[b]{2}{*}{ COL } & \multirow[b]{2}{*}{ COD } & \multirow{2}{*}{$\begin{array}{l}\text { KRP } \\
\mathrm{C}\end{array}$} & \multirow[b]{2}{*}{ KPR } \\
\hline & & & & & & & & & & \\
\hline \multicolumn{11}{|l|}{ Replicatio } \\
\hline $\mathrm{n}$ & 1 & 3520177.7 & 6.04 & 6.04 & 531.57 & 275.32 & 12.04 & 0.68 & 2.55 & 30.34 \\
\hline Location & & $35750002.5^{*}$ & $1251.92 *$ & $660.49 *$ & $56160.72 *$ & $4366.56^{*}$ & $111.56^{*}$ & & & \\
\hline$(\mathrm{L})$ & 2 & $*$ & $*$ & $*$ & $*$ & $*$ & $*$ & $3.73 * *$ & $3.73 * *$ & $145.12 * *$ \\
\hline \multicolumn{11}{|l|}{ Genotype } \\
\hline (G) & 41 & $3030130.4^{* *}$ & $5.34 *$ & $6.78^{*}$ & $261.18 \mathrm{NS}$ & $181.12 \mathrm{NS}$ & $3.47 * *$ & $0.29 * *$ & $2.64 * *$ & $21.03^{*}$ \\
\hline $\mathrm{G} \times \mathrm{L}$ & & & & & & & & $0.11 \mathrm{~N}$ & & \\
\hline \multirow[t]{2}{*}{ Interaction } & 82 & $902285^{*}$ & $2.90 \mathrm{NS}$ & $3.77 \mathrm{NS}$ & $167.83 \mathrm{NS}$ & $172.93 \mathrm{NS}$ & $1.32 \mathrm{NS}$ & S & $0.6 \mathrm{NS}$ & $8.16 \mathrm{NS}$ \\
\hline & 12 & & & & & & & & & \\
\hline Error & 5 & 655462.3 & 3.00 & 3.76 & 233.10 & 151.91 & 1.03 & 0.12 & 0.49 & 9.37 \\
\hline
\end{tabular}

$*, * *=$ Significant at 0.05 and 0.01 levels of probability, NS= Not significant, DF=Degree of freedom, GY=Grain yield, DYTS= Days to 50\% tasseling, DYSK=Days to 50\% silking, PHT=Plant height, EHT= Ear height, COL=

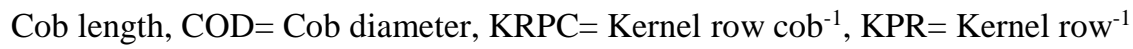

3.2 Mean Performance of genotypes for grain yield

Nine quantitative traits (i.e. off-farm and on-farm) were investigated for the 42 genotypes used in the study including their entry numbers (Table 2) and observations recorded for mean performances across the three locations (Tables $3 \& 4$ ). Due to the number of genotypes involved, comparisons between yields and other traits were limited to the seven highest ranking top cross hybrids and the three checks.

The results showed that the seven highest ranking top cross hybrids TZEI W-POP DT STRC3 x TZEI-5, Fu 2080 DWFP x TZEI-4, Fu 2090 DWDP x TZEI-46, TZEI-WPOP DT STRC3 x TZEI-1, Fu 2090 DWDP x TZEI-30, TZEI-W-POP DT STRC 3 x TZEI-39 and Fu 2080 DWDP $x$ TZEI-1 were not significantly different from each other. The highest yielding genotypes averaging 5056.8 and $5001.0 \mathrm{~kg} \mathrm{ha}^{-1}$ were TZEI-W-POP DT STRC3 $\mathrm{x}$ TZEI-5 and Fu 2080 DWFP x TZEI-4, respectively. The highest yielding check Omankwa had a mean grain yield of 4499.1 $\mathrm{kg} \mathrm{ha}^{-1}$. The seven highest ranking genotypes were not statistically different in yield from Omankwa, although TZEI-W-POP DT STRC3 x TZEI-5, Fu 2080 DWFP x TZEI-4, Fu 2090 DWDP x TZEI-46 and TZEI-W-POP DT STRC3 $\mathrm{x}$ TZEI-1 were statistically different from Aburohemaa and Akposoe. Among the checks themselves Omankwa was significantly different from Akposoe but not Aburohemaa.

Averaged across the three locations, TZEI-W-POP DT STRC3 $x$ TZEI-5 was the highest mean grain yield of $5056.8 \mathrm{~kg} \mathrm{ha}^{-1}$. Fu 2080 DWFP x TZEI-19 was the lowest grain yield of $2062.3 \mathrm{~kg} \mathrm{ha}^{-1}$. Mean grain yield was significantly higher at Kpeve (4580.0 $\left.\mathrm{kg} \mathrm{ha}^{-1}\right)$ than Fumesua (3998.0 $\mathrm{kg} \mathrm{ha}^{-1}$ ) and Ejura (3277.3 $\mathrm{kg} \mathrm{ha}^{-1}$ ). Comparison of the results of the top cross hybrids and checks revealed that the highest yielding hybrid maize, TZEI-W-POP DT STRC3 $x$ TZEI-5, had an average of $12.4 \%$ yield advantage over Omankwa, $30.6 \%$ over Aburohemaa and $66.1 \%$ over Akposoe (Table 3). The yield advantage of the different types of hybrids over the OPVs was outlined by Paliwal (2000) who observed yield advantages of $46 \%$ for single crosses, $30 \%$ for three way crosses, $23 \%$ for double crosses, $37 \%$ for double top crosses, $28 \%$ for top crosses, and $17 \%$ for variety crosses. The grain yield advantage of the top crosses could be due to the higher kernel number ear ${ }^{-1}$ (Correjado and Magulama, 2008), longer cobs and high number of rows. According to Asiedu et al. (2001), longer cobs and high number of rows are agronomic traits that plant breeders ought to look for at some stage in selecting high-yielding genotypes. This observation also supported findings of Kim et al. (1993) and Akande and Lamidi (2006) who confirmed that typical maize hybrids were found to be superior to other open pollinated maize varieties in yield potentials.

Also, majority of the hybrids evaluated in the study showed differential ranking in performance across the three locations with eight of the top cross hybrids (Fu 2080 DWDP x TZEI-1, Fu 2080 DWDP x TZEI-5, Fu 2080 DWFP x TZEI-19, Fu 2090 DWDP x TZEI-3, Fu 2090 DWDP x TZEI 36, Fu 2090 DWDP x TZEI-46, TZEI-WPOP DT STRC $3 x$ TZEI-3 and TZEI-W-POP DT STRC $3 x$ 
TZEI-47) performing likewise at either two of the locations. These dissimilar and similar rankings of top cross hybrids across the test locations are strong indications of possible existence of either crossover or non-crossover GEI and the existence of unstable genotypes. This means a closer evaluation of the top cross hybrids according to their interactions with the studied environments is indeed necessary. Differential performance of genotypes evaluated in a number of locations and in different years due to GEI was observed by Lin et al. (1986).

Table.2: List of the 42 genotypes / entries (i.e. 39 top cross hybrids and 3 checks)

\begin{tabular}{|c|c|c|c|}
\hline $\begin{array}{c}\text { Entry } \\
\text { No. }\end{array}$ & Entry name & $\begin{array}{c}\text { Entry } \\
\text { No. }\end{array}$ & Entry name \\
\hline 1 & Fu 2080 DWDP x TZEI-1 & 22 & Fu 2090 DWDP x TZEI-42 \\
\hline 2 & Fu 2080 DWDP x TZEI-4 & 23 & Fu 2090 DWDP x TZEI-45 \\
\hline 3 & Fu 2080 DWDP x TZEI-5 & 24 & Fu 2090 DWDP x TZEI-46 \\
\hline 4 & Fu 2080 DWFP x TZEI-18 & 25 & Fu 2090 DWDP x TZEI-47 \\
\hline 5 & Fu 2080 DWFP x TZEI-19 & 26 & Fu 2090 DWDP x TZEI-48 \\
\hline 6 & Fu 2080 DWFP x TZEI-22 & 27 & TZEI -W-POP DT STR C 3 x TZEI-1 \\
\hline 7 & Fu 2080 DWFP x TZEI-41 & 28 & TZEI -W-POP DT STR C3 x TZEI-2 \\
\hline 8 & Fu 2080 DWFP x TZEI-42 & 29 & TZEI -W-POP DT STR C4 x TZEI-3 \\
\hline 9 & Fu 2080 DWFP x TZEI-43 & 30 & TZEI -W-POP DT STR C3 x TZEI-4 \\
\hline 10 & Fu 2080 DWDP x TZEI-47 & 31 & TZEI -W-POP DT STR C3 x TZEI-5 \\
\hline 11 & Fu 2080 DWDP x TZEI-48 & 32 & TZEI -W-POP DT STR C3 x TZEI-34 \\
\hline 12 & Fu 2090 DWDP x TZEI-2 & 33 & TZEI -W-POP DT STR C3 x TZEI-35 \\
\hline 13 & Fu 2090 DWDP x TZEI-3 & 34 & TZEI -W-POP DT STR C3 x TZEI-36 \\
\hline 14 & Fu 2090 DWDP x TZEI-18 & 35 & TZEI -W-POP DT STR C3 x TZEI-38 \\
\hline 15 & Fu 2090 DWDP x TZEI-19 & 36 & TZEI -W-POP DT STR C3 x TZEI-39 \\
\hline 16 & Fu 2090 DWDP x TZEI-22 & 37 & TZEI -W-POP DT STR C3 x TZEI-45 \\
\hline 17 & Fu 2090 DWDP x TZEI-30 & 38 & TZEI -W-POP DT STR C3 x TZEI-46 \\
\hline 18 & Fu 2090 DWDP x TZEI-34 & 39 & TZEI -W-POP DT STR C3 x TZEI-47 \\
\hline 19 & Fu 2090 DWDP x TZEI-36 & 40 & Aburohemaa (check) \\
\hline 20 & Fu 2090 DWDP x TZEI-38 & 41 & Akposoe (check) \\
\hline 21 & Fu 2090 DWDP x TZEI-39 & 42 & Omankwa (check) \\
\hline
\end{tabular}

Table.3: Mean* performance of 42 genotypes for off-farm agronomic traits across the three locations

\begin{tabular}{llllll}
$\begin{array}{l}\text { Entry } \\
\text { No. }\end{array}$ & GY $\left(\mathbf{k g ~ h a} \mathbf{~}^{-1}\right)$ & COL $(\mathbf{c m})$ & COD $(\mathbf{c m})$ & KRPC & KPR \\
\hline \hline & & & & \\
31 & $5056.8^{\mathrm{a}}$ & $12.6^{\mathrm{ji}}$ & $4.3^{\text {ebdacf }}$ & $13.6^{\text {ilkhjg }}$ & $27.6^{\text {jihgf }}$ \\
2 & $5001.0^{\text {ba }}$ & $14.2^{\text {cebd }}$ & $4.2^{\text {ebdhgcf }}$ & $13.5^{\text {milkhjg }}$ & $31.7^{\text {bdac }}$ \\
24 & $4938.2^{\text {bac }}$ & $14.9^{\text {b }}$ & $4.2^{\text {ebdhagcf }}$ & $12.8^{\text {mln }}$ & $32.0^{\text {bac }}$ \\
27 & $4849.5^{\text {bdac }}$ & $13.4^{\text {fjeihdg }}$ & $4.5^{\text {ba }}$ & $14.4^{\text {fbedc }}$ & $29.4^{\text {ejbidhagcf }}$ \\
17 & $4781.5^{\text {ebdac }}$ & $13.1^{\text {fjeihg }}$ & $4.4^{\text {bdac }}$ & $13.7^{\text {fikhjg }}$ & $28.7^{\text {ejidhgcf }}$ \\
36 & $4703.3^{\text {ebdacf }}$ & $13.5^{\text {fjeihdg }}$ & $4.1^{\text {ebdhgcf }}$ & $13.5^{\text {milkhjg }}$ & $30.4^{\text {ebdhagcf }}$ \\
1 & $4651.2^{\text {ebdacf }}$ & $13.4^{\text {fjeihdg }}$ & $4.3^{\text {ebdagcf }}$ & $13.7^{\text {fikhjg }}$ & $28.7^{\text {ejidhgcf }}$ \\
42 & $4499.1^{\text {ebdagcf }}$ & $13.4^{\text {fjeihdg }}$ & $4.2^{\text {ebdhagcf }}$ & $13.8^{\text {fiekhjg }}$ & $27.4^{\text {jihgf }}$ \\
10 & $4451.1^{\text {ebdagcf }}$ & $14.8^{\text {cb }}$ & $4.2^{\text {ebdhagcf }}$ & $13.2^{\text {mlkjn }}$ & $32.0^{\text {bac }}$ \\
14 & $4386.9^{\text {ebdhagcf }}$ & $13.9^{\text {fcebdg }}$ & $4.3^{\text {ebdagcf }}$ & $13.7^{\text {fikhjg }}$ & $31.3^{\text {ebdac }}$
\end{tabular}




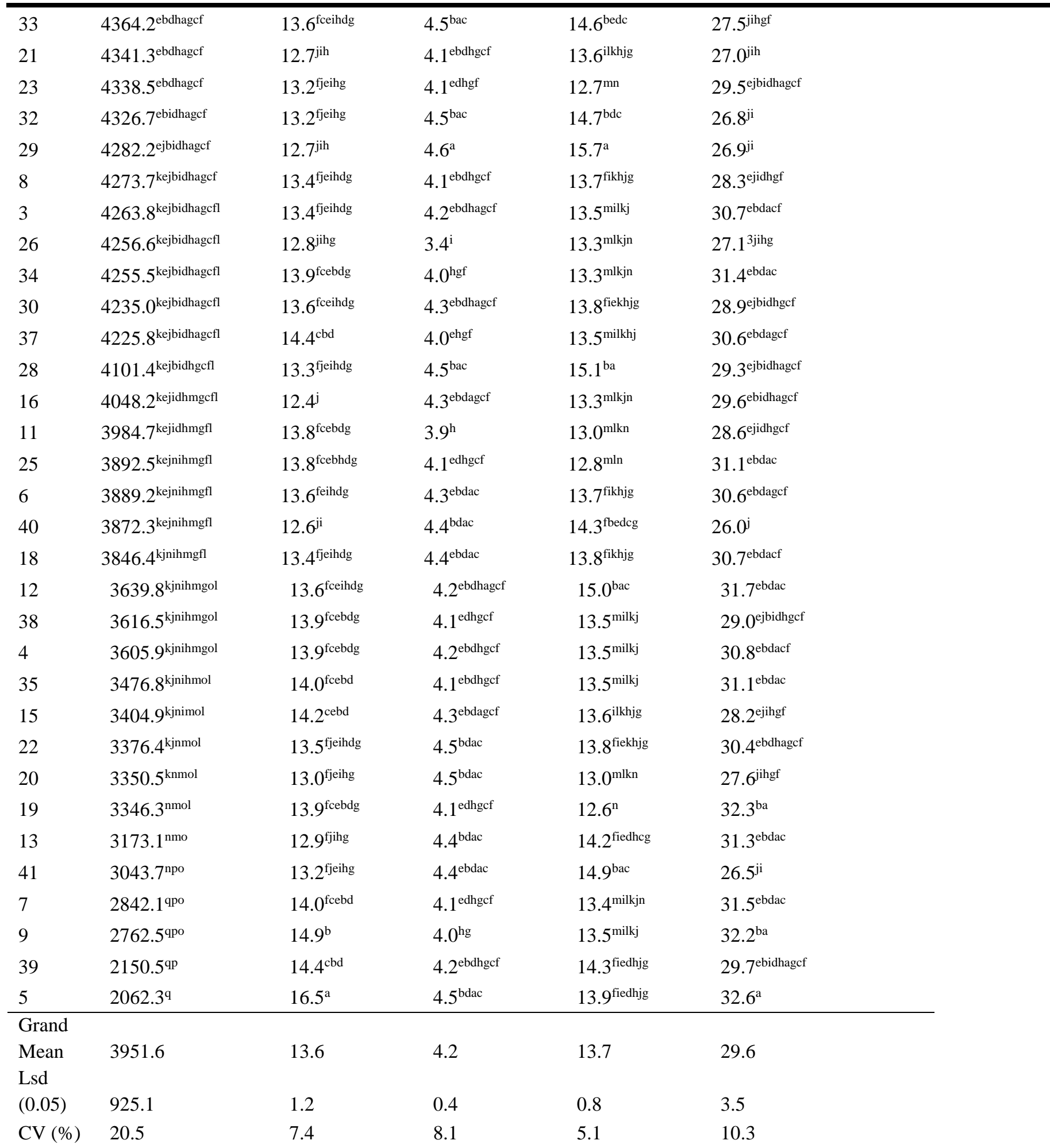

*Means with the same letter (s) within the same column are not significantly different from each other at 5\% level of probability.

Table.4: Mean* performance of 42 genotypes for on-farm agronomic traits across the three locations 


\begin{tabular}{|c|c|c|c|c|c|}
\hline Entry No. & DYSK (days) & DYTS (days) & & PHT (cm) & EHT $(\mathrm{cm})$ \\
\hline 31 & $52.2^{\mathrm{ba}}$ & $49.3^{\mathrm{bac}}$ & & $170.0^{\text {ebdgcf }}$ & $84.3^{\text {ebdfc }}$ \\
\hline 2 & $49.7^{\text {fdehg }}$ & $46.7^{\text {fihg }}$ & & $174.7^{\text {ebdacf }}$ & $89.2^{\text {ebdc }}$ \\
\hline 24 & $49.7^{\text {fdehg }}$ & $46.8^{\text {fiehg }}$ & & $183.8^{\mathrm{ba}}$ & $93.4^{\mathrm{ba}}$ \\
\hline 27 & $50.8^{\text {fbdec }}$ & $48.5^{\text {fbdec }}$ & & $182.6^{\mathrm{bac}}$ & $87.5^{\mathrm{ebdc}}$ \\
\hline 17 & $48.0^{\mathrm{h}}$ & $45.8^{\mathrm{i}}$ & & $181.2^{\text {bdac }}$ & $80.4^{\mathrm{ebdfc}}$ \\
\hline 36 & $51.8^{\text {bdac }}$ & $49.2^{\text {bdac }}$ & & $175.4^{\text {ebdacf }}$ & $87.4^{\mathrm{ebdc}}$ \\
\hline 1 & $51.0^{\text {bdec }}$ & $48.0^{\text {fbdehcg }}$ & & $163.9^{\text {edgf }}$ & $82.0^{\text {ebdfc }}$ \\
\hline 42 & $49.7^{\text {fdehg }}$ & $47.0^{\text {fiehg }}$ & & $187.8^{\mathrm{a}}$ & $103.4^{\mathrm{a}}$ \\
\hline 10 & $49.0^{\text {fehg }}$ & $46.7^{\text {fihg }}$ & & $165.5^{\text {edgcf }}$ & $76.7^{\mathrm{ef}}$ \\
\hline 14 & $49.0^{\text {fehg }}$ & $46.7^{\text {fihg }}$ & & $172.0^{\text {ebdagcf }}$ & $80.2^{\text {ebdfc }}$ \\
\hline 33 & $49.8^{\text {fdehcg }}$ & $47.0^{\text {fiehg }}$ & & $169.8^{\text {ebdgcf }}$ & $86.9^{\text {ebdfc }}$ \\
\hline 21 & $50.8^{\text {fbdec }}$ & $48.2^{\text {fbdecg }}$ & & $170.7^{\text {ebdagcf }}$ & $85.0^{\text {ebdfc }}$ \\
\hline 23 & $50.7^{\text {fbdec }}$ & $47.5^{\text {fdiehcg }}$ & & $169.3^{\text {ebdgcf }}$ & $91.0^{\text {bdac }}$ \\
\hline 32 & $51.2^{\text {bdec }}$ & $47.7^{\text {fbdiehcg }}$ & & $164.8^{\text {edgf }}$ & $83.8^{\text {ebdfc }}$ \\
\hline 29 & $51.0^{\text {bdec }}$ & $48.5^{\text {fbdec }}$ & & $166.9^{\text {ebdgcf }}$ & $82.1^{\text {ebdfc }}$ \\
\hline 8 & $49.2^{\text {fehg }}$ & $47.2^{\text {fiehg }}$ & & $161.3^{\mathrm{gf}}$ & $77.3^{\text {edf }}$ \\
\hline 3 & $49.7^{\text {fdehg }}$ & $47.2^{\text {fiehg }}$ & & $171.7^{\text {ebdagcf }}$ & $79.3^{\text {edfc }}$ \\
\hline 26 & $50.3^{\text {fbdecg }}$ & $48.0^{\text {fbdehcg }}$ & & $174.0^{\text {ebdacf }}$ & $92.6^{\mathrm{bac}}$ \\
\hline 34 & $50.0^{\text {fbdehcg }}$ & $47.5^{\text {fdiehcg }}$ & & $169.4^{\text {ebdgcf }}$ & $83.7^{\text {ebdfc }}$ \\
\hline 30 & $50.7^{\text {fbdec }}$ & $48.2^{\text {fbdecg }}$ & & $172.7^{\text {ebdagcf }}$ & $84.7^{\text {ebdfc }}$ \\
\hline 37 & $51.0^{\text {bdec }}$ & $48.7^{\text {bdec }}$ & & $169.0^{\mathrm{ebdgcf}}$ & $87.1^{\mathrm{ebdc}}$ \\
\hline 28 & $50.5^{\text {fbdec }}$ & $48.2^{\text {fbdecg }}$ & & $166.3^{\text {edgcf }}$ & $79.5^{\mathrm{ebdfc}}$ \\
\hline 16 & $49.2^{\text {fehg }}$ & $47.2^{\text {fiehg }}$ & & $169.6^{\text {ebdgcf }}$ & $81.5^{\text {ebdfc }}$ \\
\hline 11 & $48.2^{\mathrm{hg}}$ & $46.2^{\mathrm{ih}}$ & & $165.7^{\text {edgcf }}$ & $88.8^{\text {ebdc }}$ \\
\hline 25 & $50.8^{\text {fbdec }}$ & $48.0^{\text {fbdehcg }}$ & & $171.4^{\text {ebdagcf }}$ & $82.0^{\text {ebdfc }}$ \\
\hline 6 & $50.2^{\text {fbdehcg }}$ & $47.2^{\text {fiehg }}$ & & $173.2^{\text {ebdagcf }}$ & $85.2^{\text {ebdfc }}$ \\
\hline 40 & $49.5^{\text {fehg }}$ & $47.0^{\text {fiehg }}$ & & $168.1^{\text {ebdgcf }}$ & $81.2^{\text {ebdfc }}$ \\
\hline 18 & $50.7^{\text {fbdec }}$ & $47.7^{\text {fbdiehcg }}$ & & $175.1^{\text {ebdacf }}$ & $86.2^{\text {ebdfc }}$ \\
\hline 12 & $49.5^{\text {fehg }}$ & $47.2^{\text {fiehg }}$ & & $179.8^{\text {ebdac }}$ & $86.9^{\text {ebdfc }}$ \\
\hline 38 & $52.0^{\mathrm{bac}}$ & $49.5^{\mathrm{ba}}$ & & $167.8^{\text {ebdgcf }}$ & $81.8^{\text {ebdfc }}$ \\
\hline 4 & $49.8^{\text {fdehcg }}$ & $47.3^{\text {fdiehg }}$ & & $162.4^{\mathrm{egf}}$ & $85.2^{\text {ebdfc }}$ \\
\hline 35 & $50.7^{\text {fbdec }}$ & $48.2^{\text {fbdecg }}$ & & $164.9^{\text {edgf }}$ & $83.7^{\text {ebdfc }}$ \\
\hline 15 & $50.0^{\text {fbdehcg }}$ & $47.2^{\text {fiehg }}$ & & $177.8^{\text {ebdacf }}$ & $89.5^{\text {ebdac }}$ \\
\hline 22 & $53.5 \mathrm{a}$ & $50.7 \mathrm{a}$ & $166.4^{\text {ebdgcf }}$ & $91.5^{\mathrm{bac}}$ & \\
\hline 20 & $49.7^{\text {fdehg }}$ & $47.0^{\text {fiehg }}$ & $167.5^{\text {ebdgcf }}$ & $83.2^{\text {ebdfc }}$ & \\
\hline 19 & $48.7^{\text {fhg }}$ & $46.5^{\text {ihg }}$ & $175.1^{\text {ebdacf }}$ & $78.6^{\text {edfc }}$ & \\
\hline 13 & $50.8^{\text {fbdec }}$ & $47.3^{\text {fdiehg }}$ & $164.5^{\text {edgf }}$ & $82.0^{\text {ebdfc }}$ & \\
\hline 41 & $50.7^{\text {fbdec }}$ & $47.3^{\text {fdiehg }}$ & $164.5^{\text {edgf }}$ & $82.0^{\text {ebdfc }}$ & \\
\hline 7 & $49.3^{\text {fehg }}$ & $47.2^{\text {fiehg }}$ & $156.0^{\mathrm{g}}$ & $72.8^{\mathrm{f}}$ & \\
\hline 9 & $49.8^{\text {fdehcg }}$ & $47.3^{\text {fdiehg }}$ & $166.8^{\text {ebdgcf }}$ & $83.1^{\mathrm{ebdfc}}$ & \\
\hline
\end{tabular}




\begin{tabular}{llcccc}
\hline \multicolumn{1}{c}{$\begin{array}{c}39 \\
5\end{array}$} & $\begin{array}{l}50.0^{\text {fbdehcg }} \\
50.2^{\text {fbdehcg }}\end{array}$ & $\begin{array}{l}47.8^{\text {fbdehcg }} \\
48.0^{\text {fbdehcg }}\end{array}$ & $\begin{array}{l}167.7^{\text {ebdgcf }} \\
182.6^{\text {bac }}\end{array}$ & $\begin{array}{l}79.0^{\text {edfc }} \\
87.2^{\text {ebdc }}\end{array}$ \\
\cline { 2 - 5 } Grand Mean & 50.2 & 47.6 & 170.8 & 84.4 \\
Lsd (0.05) & 2.2 & 2.0 & 17.4 & 14.1 \\
CV $(\%)$ & 3.9 & 3.6 & 8.9 & 14.6 & \\
\hline \hline
\end{tabular}

*Means with the same letter (s) within the same column are not significantly different from each other at $5 \%$ level of probability.

\subsection{The GGE biplot analysis}

The GGE biplots data analysis conducted in this study showed the 'which won where' pattern (Fig. 1), mean performance and stability of tested genotypes and rankings (Fig. 2) as well as the discriminating ability and representativeness of the genotypes (Fig. 3). Fig. $1 \& 3$ were based on environment-focused singular value partitioning $(\mathrm{SVP}=2)$ suitable for studying the relationships among locations, while Fig. 2 was based on genotypefocused singular value partitioning $(\mathrm{SVP}=1)$ suitable for genotype evaluation. The biplots data was not transformed ("Transform=0"), although it was standardized ("scale =1") and environment-centered ("centering =2"). Analysis of Fig. 1, 2 \& 3 revealed that Principal Components PC1 and PC2 for Model 3 jointly explained $84.7 \%$ of total variation in grain yield of the entries due to combined location, genotype and genotype by location interaction effects.

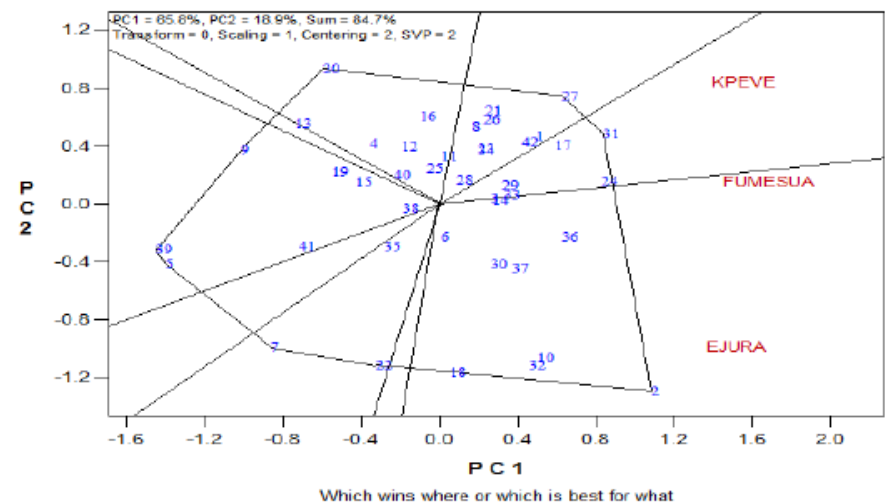

Fig.1: A 'which-won-where' view of the GGE biplot of grain yield for 42 genotypes evaluated in three locations in Ghana.

In Fig. 1, the perpendicular lines are equality lines connecting closest entries on the polygon, which make easy visual similarity of them. The equality lines split the biplot into sectors, and the winning entry for each sector was the one situated on the individual vertex (Yan and Tinker,
2006). The shape of the polygon is determined by the pointers linking the different entries that are distance away from the biplot source such that all other entries are enclosed in the polygon (Yan 2002). Hence, entries 31 (TZEI-W-POP DT $\left.\mathrm{STRC}_{3} \times \mathrm{TZEI}-5\right)$ was the winner in Kpeve, 24 (Fu 2090 DWDP x TZEI-46) in Fumesua and 2 (Fu 2080 DWFP x TZEI-4) in Ejura.

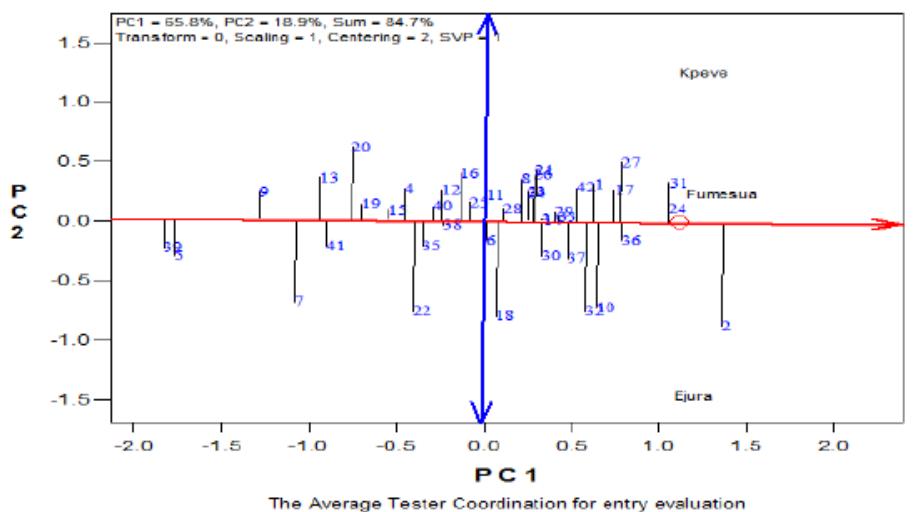

Fig.2: The "mean vs. stability" view of the GGE biplot of grain yield for 42 genotypes evaluated in three locations in Ghana.

In Fig. 2, the biplot is divided into four sectors by the single-arrowed line (AEC abscissa or $\mathrm{x}$-axis) and the double-arrowed line (AEC ordinate or y-axis). Entries on the left side of the vertical line had lower than the average yield, while those on the right had higher than average yield. The AEC abscissa points to higher mean grain yield across locations. The red circle on the AEC abscissa is referred to as the average tester yield. Hence, entry 2 (Fu 2080 DWFP $x$ TZEI-4) had the highest mean yield, followed by entries 31 (TZEI-W-POP DT $\mathrm{STRC}_{3} \times$ TZEI5), 24 (Fu 2090 DWDP x TZEI-46), 27 (TZEI-W-POP DT $\mathrm{STRC}_{3} \times$ TZEI-1), 17 (Fu 2090 DWDP x TZEI-30), 36 (TZEI-W-POP DT $\mathrm{STRC}_{3}$ x TZEI-39) and 1 (Fu 2080 DWDP $x$ TZEI-1). The stability of a genotype is determined by their projection against the $y$-axis, therefore the shorter the projection of the genotype the more stable it is (Yan et 
al., 2007). Thus, entry 24 (Fu 2090 DWDP x TZEI-46) was identified as highly stable among the seven highest yielding genotypes, followed by entries 31 (TZEI-W-POP DT $\mathrm{STRC}_{3} \times$ TZEI-5), 17 (Fu 2090 DWDP x TZEI-30), 36 (TZEI-W-POP DT STRC 3 x TZEI-39) and 1 (Fu 2080 DWDP x TZEI-1). The checks Omankwa, Aburohemaa and Akposoe were also stable.

An interesting observation from this study was that the mean vs. stability GGE biplot identified Fu 2090 DWDP x TZEI-46 as the most stable genotype. It also ranked $\mathrm{Fu}$ 2090 DWDP x TZEI-46 as the highest in yield across the locations. On the contrary, the combined ANOVA ranked TZEI-W-POP DT STRC 3 x TZEI-5 as the highest across the three locations, although the yield difference between the two hybrids was not significant. This may be due to the scaling methods used for the construction of the biplot. A similar observation was made by Yan (2002) when he reported that the choice of scaling may affect the ranking of the genotypes depending on mean performance and stability. ANOVA is usually concerned with means but GGE biplot considers both mean and variability.

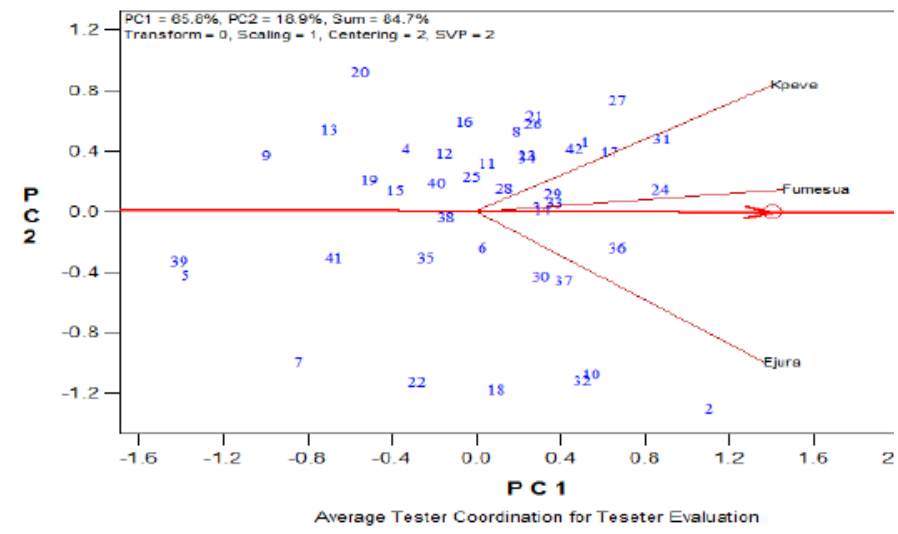

Fig. 3: The ranking of trial locations based on both discriminating ability and representativeness GGE biplot of grain yield for 42 genotypes evaluated in three locations in Ghana.

In Fig. 3, the GGE biplot presented the ideal trial location for the 42 genotypes studied across the three locations. An ideal trial location may be defined as one with high genotype discriminating ability and more representative of the broad mean of the location. While it is true that such an ideal location might not exist in actuality, it can be used as a reference for genotype selection in the multi-location yield trials. It is represented by the tiny red circle with an arrow pointing to it (Yan et al., 2007). A trial location that has the slighter angle of deviation with the AEC abscissa is more representative when compared with other trial locations. Hence, Fumesua was identified as the most ideal trial location.

3.4 Correlation between grain yield and traits of agronomic importance

The phenotypic correlation coefficients between yield and yield attributes are presented in Table 6. Grain yield exhibited positive and significant $(\mathrm{p}<0.01$ or 0.05$)$ correlation with plant height (0.550), ear height (0.458), days to $50 \%$ tasseling (0.207), days to $50 \%$ silking (0.124), cob length (0.181), cob diameter (0.246) and kernel row ${ }^{-1}$; while a non-significant association was exhibited with kernel row $\operatorname{cob}^{-1}$. The highest correlation was recorded between days to $50 \%$ silking and days to $50 \%$ tasseling (0.943). While medium values were recorded between plant height and grain yield (0.550), ear height and plant height (0.675), days to $50 \%$ tasseling and plant height (0.536), cob length and plant height (0.567) and kernel row ${ }^{-1}$ and cob length (0.678). The lowest correlation was recorded between days to $50 \%$ silking and grain yield (0.124). Nonsignificant correlations were recorded between kernel row $\mathrm{cob}^{-1}$ and grain yield, days to $50 \%$ silking and ear height, kernel row $\mathrm{cob}^{-1}$ and days to $50 \%$ tasseling, kernel row cob${ }^{1}$ and days to $50 \%$ silking, kernel row $^{-1}$ and days to $50 \%$ silking, kernel row $\operatorname{cob}^{-1}$ and cob length. A negative correlation was recorded between kernel row $^{-1}$ and kernel row $\mathrm{cob}^{-1}$. It is important to note that whenever two traits are correlated, selecting for one would ensure selection for the other trait, therefore selecting for the best of the traits that correlated with yield in this study would result in increased yields. Association between grain yield and plant height, ear height, days to $50 \%$ silking, days to $50 \%$ tasseling, cob diameter, cob length, kernel row ${ }^{-1}$ and kernel row $\mathrm{cob}^{-1}$ was also reported by Annapurna et al. (1998), Manivannan (1998) and Burak and Magoja, (1991). 
Table.6: Correlations between grain yield and other agronomic traits

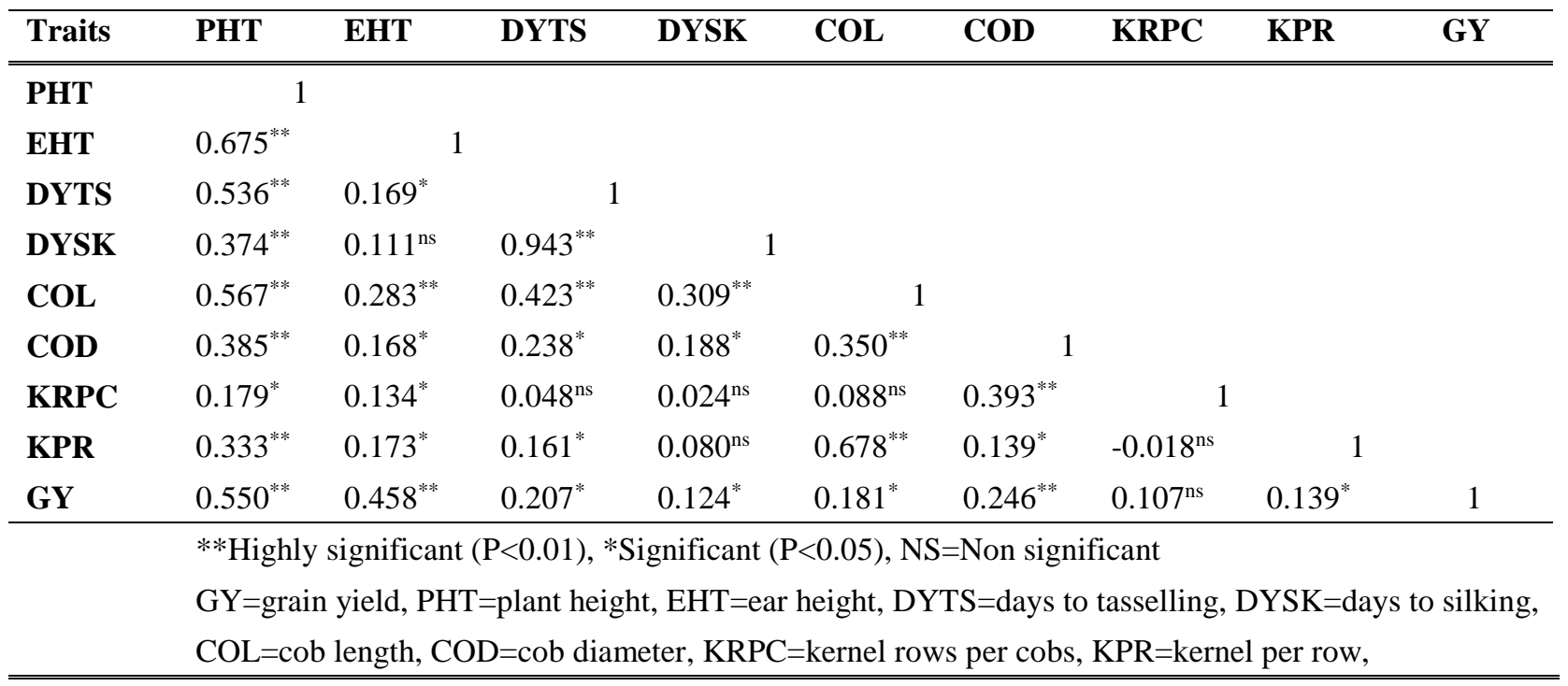

\section{CONCLUSION}

1. Traits possessing highest correlations with grain yield such as plant height and ear height can be chosen as superior characters to help improve maize grain yield. It is important to identify a variety of traits largely correlated to grain yield, which is the ultimate goal in most breeding programs.

2. The study clearly identified seven promising top cross hybrids, with the highest yielding top cross hybrid (TZEI-W-POP DT STRC 3 x TZEI-5) having a $12.4 \%$ yield advantage over the highest yielding check (Omankwa). The above results support the notion that moving from OPVs to top cross hybrids will enhance the productivity and production of maize.

3. The results from this study brought into focus the general opinion held by many stakeholders that use of hybrids hold the future of Ghanaian agriculture and that serious efforts must be made to encourage the adoption and use of superior hybrid maize varieties in Ghana as means of increasing maize productivity and production in the country.

4. Finally, the GGE biplot analysis used in this study could assist breeders to make better decisions on what genotypes should be recommended for release in Ghana.

\section{ACKNOWLEDGEMENT}

I owe an obligation of immense gratitude to the Alliance for a Green Revolution in Africa (AGRA) for providing the financial support for the implementation of this research work and a very special thanks to CSIR-CRI Maize Program for providing the germplasm used in the study

\section{REFERENCES}

[1] Akande, S.R. and Lamidi, G.O. (2006). Performance of quality protein maize varieties and disease reaction in the derived savanna agro-ecology of South West Nigeria. Institute of Agricultural Research and Training, Obafemi Awolowo University, Moor Plantation, Ibadan, Nigeria. 1-4 pp.

[2] Annapurna, D., Khan, H. A., and Mohammad, S. (1998). Genotypic-phenotypic correlations and path coefficient analysis between seed yield and other associated characters in tall genotypes of maize. Crop Research 16: 205-9.

[3] Asiedu, E.A., Sallah P.Y.K., Twumasi-Afriyie, S., Obeng-Antwi, K., Ahenkora, K. and AduseiAkowuah, P. (2001). Agronomic and post-harvest characterization of three quality protein maize (QPM) hybrids developed in Ghana. Ghana Journal of Agricultural Science 34: 57-62.

[4] Badu-Apraku, B., Ewool, M., Yallou, C.G. (2010). Registration of Striga-resistant tropical extra-early maize population. Journal of Plant Registration, Volume 4: No. 1 p. 60-66.

[5] Badu-Apraku, B., Twumasi-Afriyie, S., Sallah, P.Y.K., Asiedu, E.A., Marfo, K.A., Dapaah, S. and Dzah, B.D. (1992). The development and release of an 
early maturing streak resistant maize variety, Dorke SR. Crops Research Institute, Kumasi, Ghana. Mimeograph $21 \mathrm{pp}$.

[6] Burak, R. and Magoja, J.L. (1991). Yield and yield components of full-sib and half-sib families derived from a Perennial teosinte introgression population. Maize Genetics Corporation Newsletter 64: 67-76 Butron, A., Widstrom, N., Snook, M. and Wiseman, B. (2002). Recurrent selection for corn earworm (Lepidoptera: Noctuidae) resistance in three closely related corn southern synthetics. Journal of Economic Entomology 95: 458-462.

[7] Butron, A., Widstrom, N., Snook, M. and Wiseman, B. (2002). Recurrent selection for corn earworm (Lepidoptera: Noctuidae) resistance in three closely related corn southern synthetics. Journal of Economic Entomology 95: 458-462.

[8] Correjado Vianney, M. and Magulama Efren, E. (2008). Usefulness of improved open- pollinated varieties in the development of top-cross white maize hybrids: USM R \& D 16(2): 97-103

[9] Dankyi, A.A., Anchirinah, V.M. and Apau, A.O. (1997). Maize technology adoption in Ghana. NARP Maize Technical Report, May 1996-August 1997. National Agricultural Research Project, Crops Research Institute, Kumasi. P. 100-103.

[10] Dasbak, M.A., Echezona, B.C. and Asiegbu, J.E. (2008). Post-harvest bruchid richness and residual activity of pirimaphos methyl on Callosobruchus maculatus $F$. infested pigeon pea (cajanus cajan $L$. Mill sp.) in storage. African Journal of Biotechnology, 8(2):311-315. Department of Crop Science, University of Nigeria.

[11]FAO Statistical Databases. (2008). FAOSTAT: Agriculture Data. Available online: http://faostat.fao.org.

[12] Kim, S.K., Fajemisin, J.M., Fakorede, M.A.B. and Iken, J.E. (1993). Maize improvement in Nigeria: Hybrid performance in the savanna zone. In: Maize improvement, production and utilization in Nigeria. Fakorede, M.A.B., Alofe, C.O. and Kim, S.K. (Eds.), pp. 41-46. Maize Association of Nigeria.

[13] Lin, C.S., Binns, M.R. and Lefkovitch, L.P. (1986). Stability analysis: Where do we stand? Crop Science 26: 894- 900

[14] Manivannan, N.A. (1998). Character association and components analysis in maize. Madras Journal of Agriculture 85:293-294.
[15] Ministry Of Food and Agriculture (MOFA). (2011a). Agriculture in Ghana: Facts and Figures (2010). Statistics, Research and Information Directorate (SRID).

[16] Ministry Of Food and Agriculture (MOFA). (2006). Statistics, Research and Information Directorate. Agriculture in Ghana: Facts and Figures

[17] Morris, M.L., Tripp, R. and Dankyi, A.A. (1999). Adoption and impacts of improved maize production technology. A case study of the Ghana Grains Development Project, Economics Program Paper 9901. Mexico, D.F., CIMMYT. Available Online http://www.

CIMMYT.

Org./Research/Economics/Map/Research

Results/Program Papers/pdf/EPP\% 2099 01.pdf.

[18] Ogunbodede, B.A., Ajibade, S.R. and Olakojo S.A. (2001). Grain yield stability of new maize varieties in Nigeria: African Crop Science Journal, Volume 9: No. 4, pp. 685-691

[19] Pswarayi, A. and Vivek, B.S. (2007). Combining ability amongst CIMMYT's early maturing maize (Zea mays L.) germplasm under stress and non-stress conditions and identification of testers. Eupytica.

[20] Sallah, P. Y. K., Abdulai, M. S. and Obeng-Antwi, K. (2004). Genotype x environment interactions in three maturity groups of maize cultivars: African Crop Science Journal, Volume 12: No. 2, pp. 95-104

[21] Sallah, P. Y. K., Ewool, M. B. and Obeng-Antwi, K. (2001). Effects of drought stress on composite and hybrid maize cultivars in Ghana. Agriculture and Food Science Journal of Ghana. 1:17-29

[22] Sallah, P.Y.K., Twumasi-Afriyie, S., Asiedu, E.A., Obeng-Antwi, K., Boa-Amponsem, K., Ahenkora, K., Agyemang, A. and Lampoh, E.K. (1997). Development and 101 release of Dodzi, an extra-early maturing maize variety in Ghana. Crops Research Institute, Kumasi, Ghana. Mimeograph. 28pp.

[23] SAS Institute, (2002). Statistical Analysis Software (SAS) user's guide Version 9.2. SAS Institute, Inc., Cary, NC, USA. Soza, R. F., Asafo-Adjei, B., Twumasi-Afriyie, S., Adu Tutu, K. O. and BoaAmponsem (1996). Increasing maize productivity in Ghana through an integrated research extension approach. Paper presented at the $5^{\text {th }}$ Regional Maize Conference organized by CIMMYT held in Arusha-Tanzania from June 3-7, 1996. 9pp.

[24] Soza, R. F., Asafo-Adjei, B., Twumasi-Afriyie, S., Adu Tutu, K. O. and Boa-Amponsem (1996). Increasing maize productivity in Ghana through an 
integrated research extension approach. Paper

presented at the 5th Regional Maize Conference organized by CIMMYT held in Arusha-Tanzania from June 3-7, 1996. 9pp.

[25] Twumasi-Afriyie, S., Sallah, P.Y.K., Ahenkora, K., Asiedu, E.A., Obeng-Antwi, K., Frimpong-Manso, P.P., Osei-Yeboah, S., Apau, A.O., Mensah-Ansah, A., Haag, W. and Dzah, B.D. (1997). Development and release of three quality protein maize hybrid varieties, Dadaba, Mamaba and CIDA-ba in Ghana. Crops Research Institute, Kumasi. 31pp

[26] Yan, W., Kang, M.S., Ma, B., Woods, S. and Cornelius, P.L. (2007). GGE biplot vs. AMMI analysis of genotype-by-environment data. Crop Science 47: 643-655.

[27] Yan, W., Tinker, N.A. (2006). Biplot analysis of multi-environment trial data: Principles and applications. Canadian Journal of Plant Science 86: 623-645

[28] Yan, W. (2001). GGE Biplot- A windows application for graphical analysis of multi-environment trial data and other types of two-way data. Agronomy Journal 93:1111-1118.

[29] Yan, W. (2002). Singular value partitioning in biplot analysis of multi-environment trial data. Agronomy Journal 94: 990-996 